\title{
CRITÉRIOS DE EXPLORAÇÃO DOS METADOLOMITOS DA REGIÃO DE MORRO GRANDE, COLOMBO-PR
}

\author{
ROSSANO BILL LOPES DE SIQUEIRA*
}

\author{
DISSERTAÇÃO DE MESTRADO - Programa de Pós-Graduação em Geologia - UFPR \\ DATA DE DEFESA: 11 out. 2001
}

Apesar da grande utilidade do calcário e das grandes reservas que o estado possui deste bem mineral, ele é explorado preferencialmente para aplicações que possuem, baixo valor agregado. No Paraná, as rochas calcárias de idade Mesoproterozóica existentes na Região Metropolitana de Curitiba são as rochas mais importantes em distribuição geográfica quanto ao aproveitamento econômico. O presente trabalho consistiu na verificação e discussão dos principais critérios de exploração utilizados pelas empresas de mineração na Formação Capirú, seqüências litológicas Morro Grande e Rio Branco na região de Morro Grande, no limite entre os municípios de Colombo e Rio Branco do Sul, através do estudo e compreensão das formas de lavra e pesquisa adotadas pelas empresas de mineração, e assim contribuir para uma melhor utilização desse calcário e com isso elevar o grau de conhecimento prospeccional, visto que o desconhecimento das reservas e qualidades da matéria-prima é a causa imediata da falta de investimentos estratégicos no setor. Os principais litotipos na área de estudo são: metadolomitos, filitos e quarzitos representativos de uma seqüência plataformal carbonática $e$ metamorfisados em baixo grau. Neste trabalho foram analisados critérios de exploração relacionados aos sistemas deposicionais, que mostraram a preferência das grandes empresas de mineração pela Seqüência Litológica Morro Grande (SLMG), embora represente uma estreita faixa metadolomítica em relação à Seqüência Litológica Rio Branco (SLRB). De acordo com as principais características a SLMG é representativa de zona de supramaré, com metadolomitos de granulação fina, intercalações de níveis cinza-claro e cinza-escuro e camadas com grandes espessuras enquanto a SLRB apre- senta metadolomitos de granulação fina a média, estratificação cruzada e camadas pouco espessas, representativa de zona de inframaré. A partir da elaboração de colunas litoestratigráficas, pôde-se determinar as características de cada litotipo e a possível relação entre eles do ponto de vista de exploração. A utilização da análise petrográfica e colorimétrica foi igualmente eficiente, pois permitiu distinguir as seqüências litológicas pela sua granulação, textura, \% de insolúveis e a distinção entre calcita e dolomita em secões delgadas. Através da análise química, pôde-se determinar os litotipos com maiores teores de insolúveis, visto que estes prejudicam a qualidade do material explotado, e, desta forma selecionar os níveis mais indicados do ponto de vista econômico. A partir da gamaespectrometria terrestre, pôde-se separar as duas seqüências litológicas e as possíveis zonas de falhas, através dos diferentes padrões de assinaturas dos radioelementos potássio $(\mathrm{K})$, urânio $(\mathrm{U})$, tório $(\mathrm{Th})$ e contagem total (CT). Os aspectos geológicosgeomorfológicos, através da elaboração do mapa clinográfico indicaram que as faixas com as mais elevadas cotas altimétricas (correspondentes aos litotipos da SLMG) apresentam também as encostas com maiores declividades e menores espessuras de tálus, sendo a seqüência litológica com maior concentração de pedreiras em termos de volume e material explotado. Já a análise dos dados estruturais permitiu determinar que a Sinforme de Morro Grande teve uma influência importante para a exploração, pois este grande dobramento criou maior inclinação das camadas e elevou-as tornando-as mais expostas, apesar de não existir um controle quanto às alturas das bancadas. 